Endocrinol. Japon. 1989, 36 (2), 281-288

\title{
Serum Parathyroid Hormone Concentration Measured by Highly Sensitive Assay in Post-Thyroidectomy Hypocalcemia of Patients with Graves' Disease
}

\author{
Noboru HAMAdA ${ }^{1}$, TAKAShi MIMURA ${ }^{2}$, AkIRA SUZUKI ${ }^{3}$, \\ JAEDUCK $\mathrm{NOH}^{3}$, JUNICHI TAKAZAWA ${ }^{4}$, TAKASHI IIJIMA ${ }^{4}$, \\ Kunihiko ITO $^{3}$ AND HiRotoshi MORII ${ }^{1}$
}

\author{
${ }^{1}$ Second Depatment of Internal Medicine, Osaka City University, Abenoku, Osaka 545 \\ ${ }^{2}$ Department of Surgery, Saiseikai Central Hospital, Minatoku, Tokyo 108 \\ ${ }^{3}$ Ito Hospital, Shibuyaku, Tokyo 150 \\ ${ }^{4}$ Reseach Laboratory, Yamasa Shoyu, Choshi, Chiba 288, Japan
}

\begin{abstract}
To investigate the role of parathyroid function in transient hypocalcemia after subtotal thyroidectomy for Graves' disease, the serum parathyroid hormone (PTH) concentration and nephrogenous (N) cAMP were measured in 16 patients before and after surgery. Serum PTH was measured with two commercially available kits (PTH-M, PTH-C), PTH-M is a recently developed highly sensitive assay using an antibody recognizing the mid-portion of human PTH and a synthetic ${ }^{125}$ I-tyr ${ }^{45}$-human PTH (43-68) as a radioligand. One of the 16 patients had severe clinical tetany and had a markedly lower PTH-M concentration and NcAMP after thyroidectomy. However, no significant change in serum PTH-M, PTH-C and NcAMP were observed in the other patients, although their serum calcium $(\mathrm{Ca})$ concentrations decreased significantly.

The Data were analyzed by dividing the patients according to the change in serum Ca or PTH. Serum PTH-M and PTH-C significantly decreased in 4 patients whose serum $\mathrm{Ca}$ clearly decreased after surgery. Serum $\mathrm{Ca}$ on the first postoperative day was significantly lower in patients whose serum PTH decreased after thyroidectomy than in patients whose serum PTH did not. Furthermore, the serum Ca concentration was significantly correlated with PTH-M, and with NcAMP on the third postoperative day. These data proved that hypofunction of the parathyroid gland is important in transient hypocalcemia after subtotal thyroidectomy for Graves' disease. The pathogenetic mechanism of transient hypocalcemia was discussed in comparison with the data from a patient who had overt parathyroid injury.
\end{abstract}

Received December 23, 1988

All editorial correspondence and requests for reprints should be addressed to NOBORU HAMADA, M.D., Second Department of Internal Medicine, Osaka City University, 1-5-7, Asahimachi, Abenoku, Osaka 545, Japan
Transient hypocalcemia is occasionally seen after subtotal thyroidectomy for Graves' disease, which is considered to be different from the permanent hypocalcemia caused by parathyroid insufficiency. To date, four hypothetical mechanism have been suggested 
for this transient hypocalcemia: 1) functional hypoparathyroidism (Davis et al., 1961; Ridell, 1962), 2) the reversal of thyrotoxic osteodystrophy (Michie et al., 1971; Latin, 1976), 3) the release of calcitonin (CT) during thyroid manipulation, (Wilkin et al., 1977; Fukunaga et al., 1977; Kobayashi, 1981; Watson et al., 1981) and reduction in the renal tubular reabsorption of calcium, (Percival et al., 1985) but there is no conclusive proof. In particular, the role of parathyroid hormone (PTH) in the pathogenesis is not known, because there has not been an assay for PTH sensitive enough to evaluate the changes in serum PTH after thyroidectomy. Recently, a highly sensitive assay for PTH was developed using antisera with a high affinity for circulating PTH (Hurska et al., 1975) and synthetic human (h) PTH (43-68) as a radioligand (Fukunaga et al., 1987; Kawakubo et al., 1986). Using this assay, significantly low PTH concentrations were found in sera of patients with idiopathic hypoparathyroidism and hyperthyroidism. In this study, therefore, to investigate the role of parathyroid function in transient hypocalcemia after subtotal thyroidectomy for Graves' disease, we measured nephrogenous cAMP and serum PTH concentrations by this highly sensitive assay before and after surgery.

\section{Patients and Methods}

Eleven female and 5 male patients undergoing subtotal thyroidectomy for Graves' disease were studied. A diagnosis of Graves' disease was established by diffuse goiter, an increased serum thyroid hormone concentration, and ${ }^{131}$ I-thyroidal uptake. All the patients were treated with methimazole and Lugol solution, and were euthyroid on operation day (D-1). All medications were withdrawn on D-1 and none was reintroduced during the period of study. Local anesthesia with $0.5 \%$ procaine was used. Blood samples were obtained and urine was collected at 8:00a.m. after overnight fasting and urina- tion at 7:00 a.m. before surgery (D-1) and on the first $(D+1)$, third $(D+3)$ and the fifth $(D+5)$ postoperative days. In addition to the measurement of serum PTH, serum and urine $\mathrm{Ca}, \mathrm{P}$, creatinine, and cAMP were measured and the nephrogenous cAMP (NcAMP) concentration was calculated.

\section{Measurement of PTH}

Serum PTH was measured with two commercially available kits (PTH Kit "YAMASA", Yamasa Shoyu Co. Ltd, Choshi, Chiba, PTH-C "EIKEN", Eiken Immunochemical Laboratory, Tokyo, Japan). The PTH kit "YAMASA" (PTH-M) is the one described in the introduction; it is a double antibody radiomimmunoassay using chicken anti-bovine PTH (1-84) antibody (Hurska et al. 1975) as the first antibody, synthetic ${ }^{125} \mathrm{I}_{-} \mathrm{tyr}^{42}$-hPTH $(43-68)$ as the radioligand, and synthetic hPTH (1-84) as a standard. The minimum detectable value was $0.10 \mathrm{ng} / \mathrm{ml}$, and the normal range of serum PTH-M was $0.36 \pm 0.006 \mathrm{ng} / \mathrm{ml} \quad(\operatorname{mean} \pm \mathrm{SE}, \mathrm{n}=255)$. Intraassay variance was $2.8-4.6 \%$ and inter-assay variance was 6.8-8.6\%. PTH-C "EIKEN" (PTH-C) is also a double antibody radioimmunoassay, using guinea pig anti-hPTH (46-84) antibody as the first antibody, synthetic ${ }^{125}$ I-tyr ${ }^{45}$-hPTH (4684) as a standard. The minimum detectable value, normal range of serum PTH-C and intraand inter-assay variances were reported to be $0.10 \mathrm{ng} / \mathrm{ml}, \quad 0.28 \pm 0.03 \mathrm{ng} / \mathrm{ml}, \quad 9.2-14.3 \%$ and $12.5 \%$, respectively, (Ishihara et al., 1984).

NcAMP was calculated as follows (Broadus et al. 1977):

\begin{tabular}{|c|c|}
\hline \multicolumn{2}{|c|}{$\mathrm{UcAMP} \times \mathrm{Uv}-\mathrm{PcAMP} \times \mathrm{Ccr}$} \\
\hline & Cer \\
\hline UcAMP & $\begin{array}{l}\text { cAMP concentration in urine } \\
(\mathrm{pmol} / \mathrm{ml})\end{array}$ \\
\hline Uv : & urine volume $(\mathrm{ml} / \mathrm{min})$ \\
\hline PcAMP : & $\begin{array}{l}\text { cAMP concentration in plasma } \\
(\mathrm{pmol} / \mathrm{ml})\end{array}$ \\
\hline Ccr : & Creatinine Clearance $(\mathrm{m} 1 / \mathrm{min})$ \\
\hline
\end{tabular}

Normal range of NcAMP was $1.70 \pm 0.559$ $($ mean $\pm S D, n=43) n m o l / d 1 G F$.

\section{Statistical analysis}

The significance of the difference between two means was determined by Student's $t$-test or paired Student's $t$-test. Unless otherwise stated, Student's $t$-test was used. 


\section{Results}

One patient in this series (Y.S.) had severe clinical tetany, but others did not complain of any symptoms of hypocalcemia. Y.S. was considered to have suffered parathyroid damage because the intravenous infusion of $\mathrm{Ca}$ and ingestion of active vitamin D were necessary for the control of hypocalcemia. Hereafter, we will discuss the data divided into the case of Y.S. and the others. When we do not mention the source, the data refer to patients other than Y.S.

Serum Ca was significantly decreased on $\mathrm{D}+3$, and $\mathrm{D}+5$, and serum $\mathrm{P}$ also tended to decrease, while serum $P$ increased in the case of Y.S. (Table 1). Serum PTH-C did not significantly change during the period of study. Even in the case of Y.S., it was not significantly different from the data for the others (Fig. 1). In contrast to serum PTH-C, serum PTH-M had a tendency to decrease after surgery, but this was not significant. In addition, hypoparathyroidism in the case of Y.S. was clearly demonstrated by the measurement of serum PTH-M. A1- though the changes in NcAMP were not significant for the others, it decreased in the case of Y.S. These findings indicate that 1) the presence of overt parathyroid insufficiency can be shown by the measurement of PTH-M and NcAMP, while it cannot by PTH-C, and 2) when the data were analyzed in all the patients, parathyroid function tended to fall but it was not significant.

Then the patients were divided into two groups according to the change in serum $\mathrm{Ca}$, that is, when the sum of the decreases in serum $\mathrm{Ca}$ on $\mathrm{D}+1, \mathrm{D}+3$, and $\mathrm{D}+5$ from that on D-1 was $13 \mathrm{mg}$ or more (A) or less than $13 \mathrm{mg}$ (B) (Fig. 2). Group A consisted of 4 patients, whose serum concentration of $\mathrm{Ca}$ decreased significantly on $\mathrm{D}+1, \mathrm{D}+3$, and $\mathrm{D}+5$; in the 11 patients in group $\mathrm{B}$, the serum $\mathrm{Ca}$ concentration did not change significantly. Moreover, serum PTH-M and PTH-C concentrations decreased significantly after thyroidectomy in group $A$ as analyzed by a paired Student's $t$-test (Fig. 2). These data were also analyed in the opposite way. That is, the patients were divided into two groups according to the change in serum PTH. In

Table 1. Changes in serum and urine Ca, $P$ and \%TRP on operation day (D-1), and the first $(D+1)$, third $(D+3)$, and fifth $(D+5)$ postoperative days in 15 patients with Graves' disease.

\begin{tabular}{lllll}
\hline & \multicolumn{1}{c}{$\mathrm{D}-1$} & \multicolumn{1}{c}{$\mathrm{D}+1$} & \multicolumn{1}{c}{$\mathrm{D}+3$} & \multicolumn{1}{c}{$\mathrm{D}+5$} \\
\hline Serum Ca & $9.28 \pm 0.07^{\mathrm{a}}$ & $9.09 \pm 0.11$ & $8.92 \pm 0.09^{*}$ & $8.92 \pm 0.05^{*}$ \\
& $(9.4)$ & $(7.0)$ & $(7.8)$ & $(8.0)$ \\
Serum P & $4.13 \pm 0.13$ & $3.85 \pm 0.11$ & $3.62 \pm 0.09^{*}$ & $3.86 \pm 0.11$ \\
& $(4.7)$ & $(5.6)$ & $(5.3)$ & $(5.1)$ \\
Urine $\mathrm{Ca} / \mathrm{Cr}$ & $0.051 \pm 0.014$ & $0.072 \pm 0.017$ & $0.086 \pm 0.021$ & $0.083 \pm 0.014$ \\
& $(0.245)$ & $(0.116)$ & $(0.157)$ & $(0.135)$ \\
Urine P/Cr & $0.455 \pm 0.370$ & $0.847 \pm 0.102^{*}$ & $0.440 \pm 0.040$ & $0.424 \pm 0.031$ \\
& $(0.627)$ & $(0.202)$ & $(0.756)$ & $(0.313)$ \\
\%TRP & $91.8 \pm 0.94$ & $85.6 \pm 1.57^{*}$ & $92.3 \pm 0.57$ & $92.9 \pm 0.52$ \\
& $(93.3)$ & $(98.2)$ & $(92.9)$ & $(96.9)$ \\
\hline
\end{tabular}

${ }^{\mathrm{a}}:$ mean \pm SE, $\mathrm{n}=15$

$* \mathrm{p}<0.05$, when compared to D-1.

The numbers in parenthesis indicate the values in the case of Y.S. who had severe clinical tetany after surgery. 


\section{PTH}

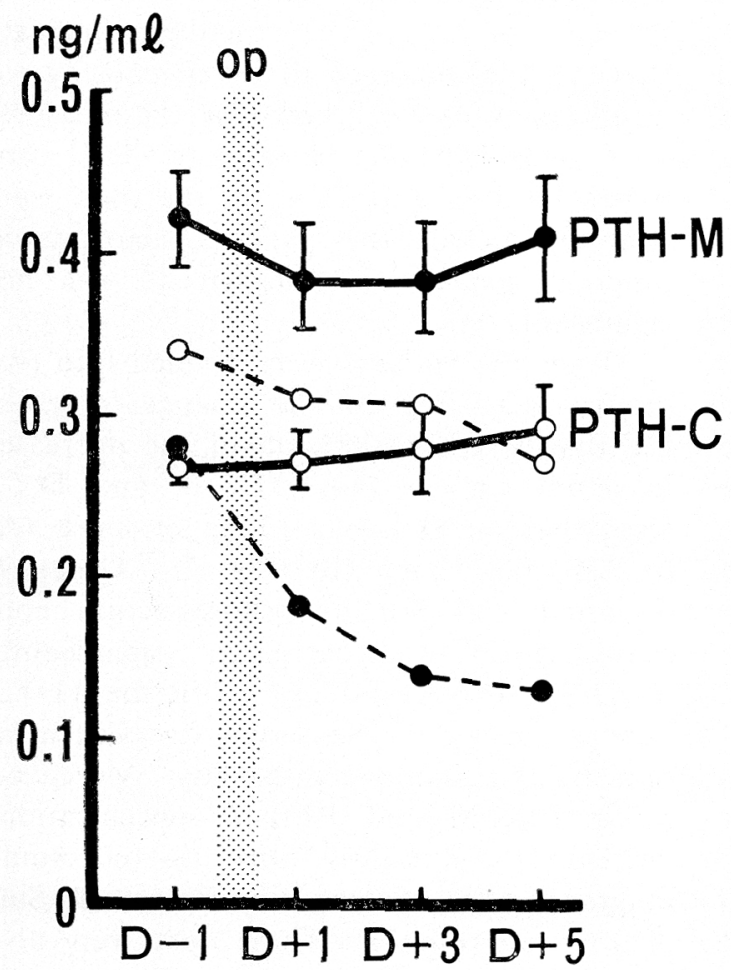

Nephrogenous cAMP $\mathrm{nmol} / \mathrm{d} \ell \mathrm{GF}$

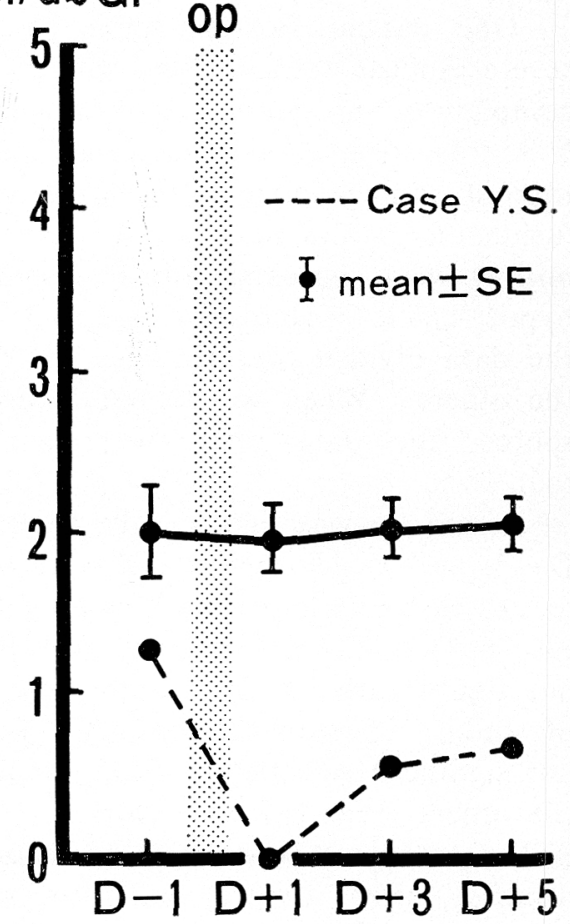

Fig. 1. Changes in serum PTH-M (closed circles) and PTH-C (open circles) concentrations, and NcAMP before and after subtotal thyroidectomy for Graves' disease. The solid line represents the data for 15 patients without clinical symptoms of hypocalcemia and the broken line the data for the case of Y.S. who had severe clinical tetany after surgery. D-1: Operation day, $\mathrm{D}+1, \mathrm{D}+3$ and $\mathrm{D}+5$ : The first, third and the fifth postoperative days.

9 patients whose serum PTH-M decreased after surgery, the serum $\mathrm{Ca}$ concentration $(8.78 \pm 0.14:$ mean $\pm S E)$ on $D+l$ was significantly lower than that $(9.42 \pm 0.15)$ in the 6 patients whose serum PTH-M was not decreased after surgery. A decrease in serum PTH was defined to be when both values on $\mathrm{D}+1$ and $\mathrm{D}+3$ were lower than that on D-1. In addition, in 6 patients whose serum PTH-C decreased after surgery, the serum $\mathrm{Ca}$ concentration $(8.66 \pm 0.163$ $\mathrm{g} / \mathrm{dl})$ on $\mathrm{D}+3$ was significantly lower than that $(9.08 \pm 0.124)$ in 9 patients whose serum PTH-C was not decreased after surgey.

Serum PTH-M correlated positively with serum $\mathrm{Ca}$ on $\mathrm{D}+3 \quad(\mathrm{r}=0.496, \mathrm{p}<0.05)$.
Furthermore, a significantly positive correlation was observed between NcAMP and serum Ca (Fig. 3). The significant correlations seemed to be due to the inclusion of patient Y.S. who probably had more significant parathyroid injury. Even if the correlation analysis was done in 15 patients except patient Y.S., however, the correlation between NcAMP and serum Ca was significant $(r=0.489, p<0.05)$.

The changes in urinary excretion of $\mathrm{Ca}$ and $\mathrm{P}$ expressed as $\mathrm{Ca} / \mathrm{Cr}$, and $\mathrm{P} / \mathrm{Cr}$ are shown in Table 1. After thyroidectomy, both urinary $\mathrm{Ca}$ and $\mathrm{P}$ excretion tended to increase and the increase in urinary $P$ excretion was significant on $\mathrm{D}+1$. The 

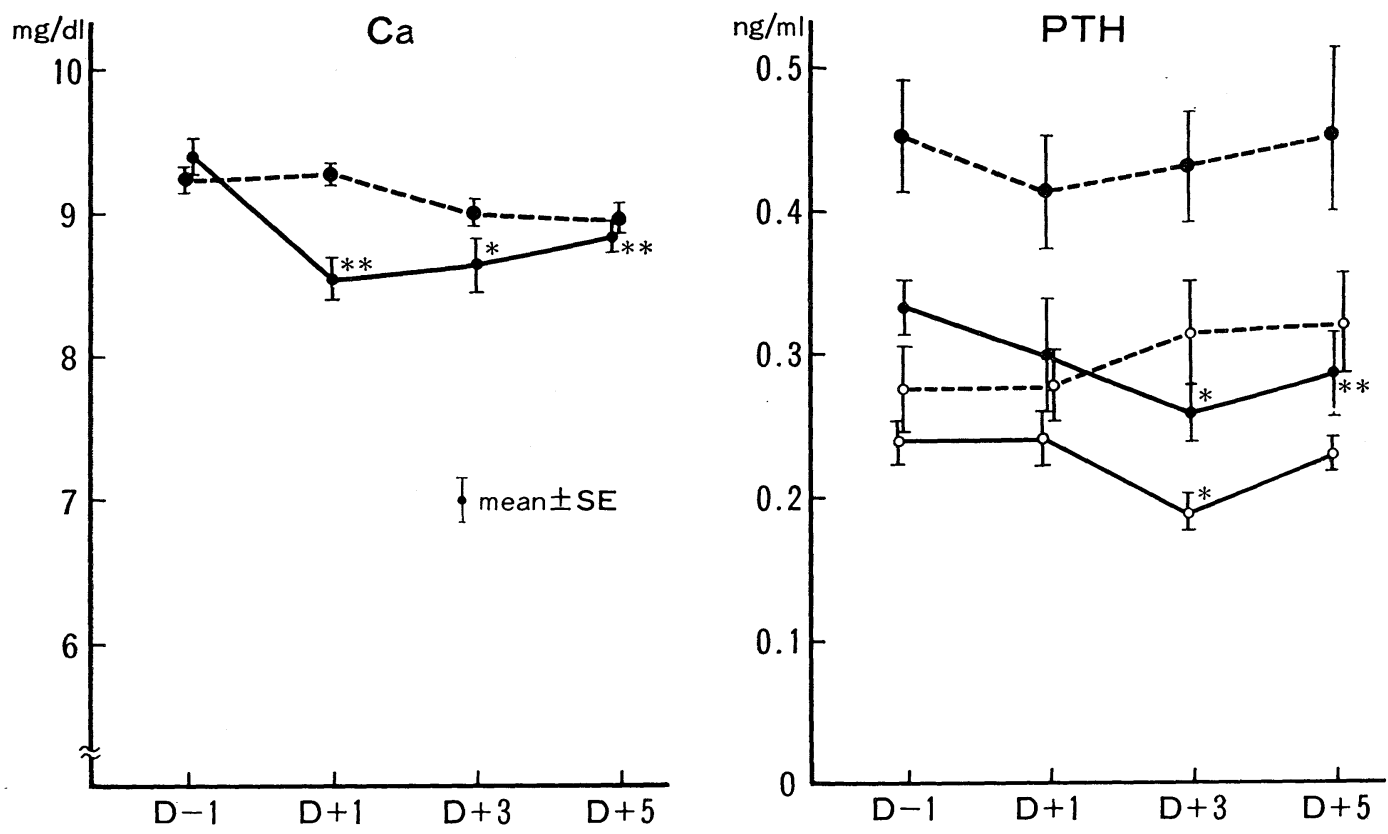

Fig. 2. Changes in serum Ca, and PTH-M (closed circles) and PTH-C (open circles) concentrations before and after subtotal thyroidectomy in 4 Graves' patients who had clear decreases in serum $\mathrm{Ca}$ (solid line, group $\mathrm{A}$ in text) and 11 patients who did not (broken line, group B). In the left figure, $* \mathrm{p}<0.05, * * \mathrm{P}<0.01$ when compared to the value on D-1. In the right figure, ${ }^{*} \mathrm{p}<0.05,{ }^{* *} \mathrm{p}<0.01$ when compared to the value on $\mathrm{D}-1$ by paired Student's $t$-test. $\mathrm{D}-1$ : Operation day, $\mathrm{D}+1, \mathrm{D}+3$ and $\mathrm{D}+5$ : The first, third and the fifth postoperative days.

percentage of tubular reabsorption of $\mathrm{P}$ (\%TRP) significantly decreased on $\mathrm{D}+1$, while it increased in the case of Y.S. Decrease in \%TRP and the increase in urinary $\mathrm{P}$ excretion on $\mathrm{D}+1$ were observed even in group A patients.

\section{Discussion}

Functional hypoparathyroidism has been thought to be one of the causes of transient hypocalcemia after subtotal thyroidectomy (Davis et al., 1961; Ridell, 1962). However, no reports have shown a definite decrease in the serum PTH concentration. This may be due to the low sensitivity of the PTH assay (Berson et al., 1963; European PTH Study Group, 1978; Voll et al.,
1978). The problems with the assay include the scarcity of an antiserum with high affinity for the circulating form of PTH, the scarcity of ligands for radioiodination, and the heterogeneity of the immunoreactivity of circulating species of PTH. Two papers reported changes in the serum immunoreactive PTH concentration in post-thyroidectomy hypocalcemia (Watson et al., 1981; Percival et al., 1985) but no significant decrease in serum PTH was demonstrated. Also, in our study, the serum PTH-C concentration in the case of Y.S. who had overt parathyroid injuly tended to decrease but was not significantly different from those of the other patients. In contrast, the parathyroid insufficiency of Y.S. was clearly demonstrated by a significant decrease in serum PTH-M. It has been 


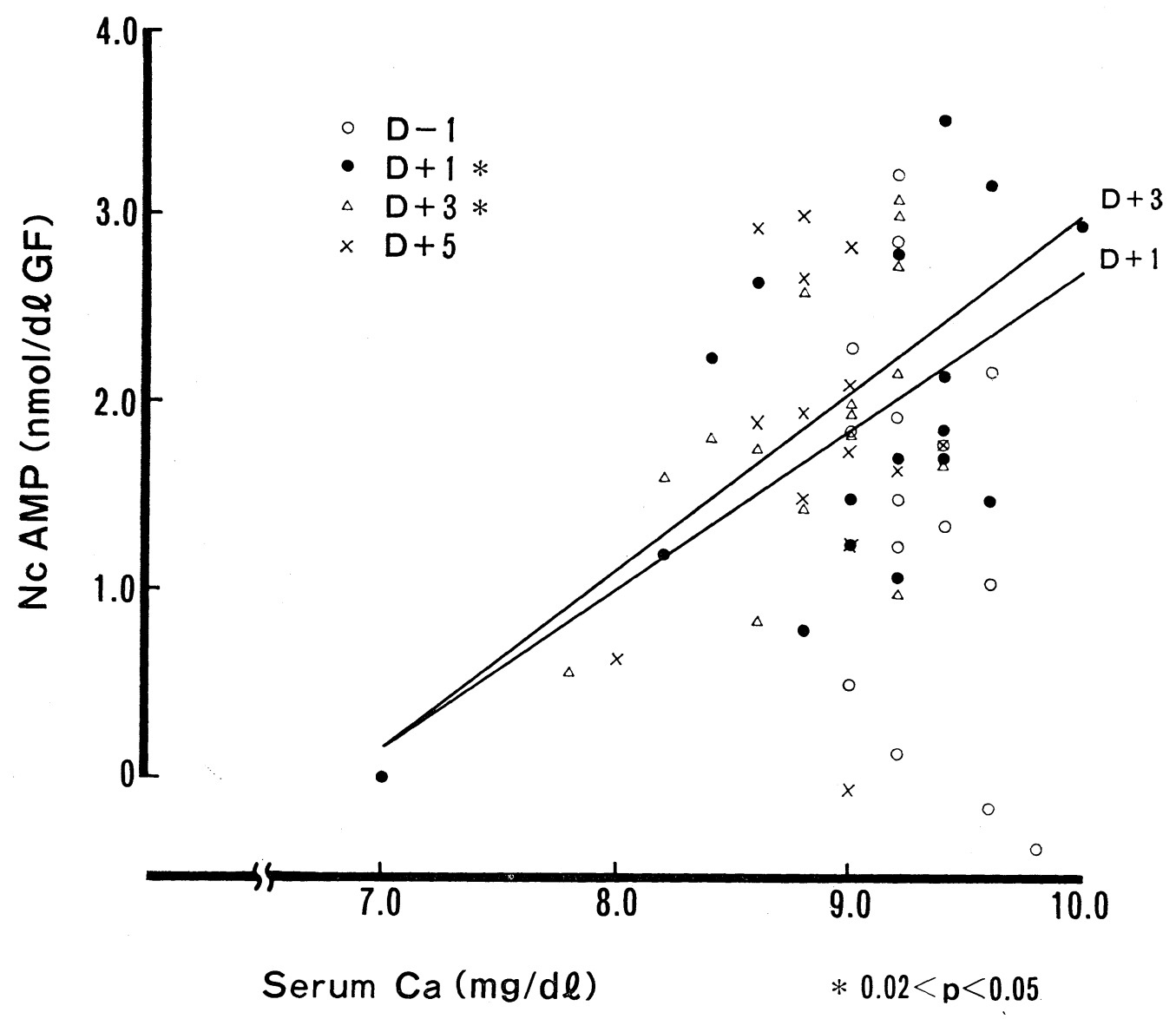

Fig. 3. Correlation between NcAMP and serum $\mathrm{Ca}$ on operation day (D-1: $\bigcirc$ ), and the first $(\mathrm{D}+1: \bigcirc)$ third $(\mathrm{D}+3: \Delta)$, and fifth $(\mathrm{D}+5: \times)$ postoperative days in 16 patients with Graves' disease. Case Y.S. was included. The correlation coefficients on $\mathrm{D}+1$ and $\mathrm{D}+3$ are $0.530, \mathrm{p}<0.05$ and $0.565, \mathrm{p}<0.05$, respectively.

reported difficult to differentiate hypoparathyroidism from normal subjects by the PTH-C assay (Ishihara et al., 1984). The difference between PTH-M and PTH-C sensitivity may be due to the difference in the affinities of antibodies to circulating PTH, since PTH-M and PTH-C recognized almost the same mid portion of hPTH (PTH-M : 43-68, PTH-C： 39-68) (Fukunaga et al., 1987; Kawakubo et al., 1986). Either way, serum PTH-M and PTH-C concentrations significantly decreased in group A patients whose serum $\mathrm{Ca}$ decreased after surgery.

Furthermore, significantly lower concentrations of serum $\mathrm{Ca}$ were observed in patients whose serum PTH decreased after surgery, whichever PTH assay was used. Although the PTH-C value may not be good enough for comparison among the patients, its changes in the same individual are thought to be reliable. These data suggested that parathyroid function declines in patients with hypocalcemia after thyroidectomy. In addition, NcAMP, which may represent PTH action on the renal tubules 
(Broadus et al., 1977), was significantly correlated with the serum $\mathrm{Ca}$ concentration. We concluded that hypofunction of the parathyroid gland may be important in transient hypocalcemia after subtotal thyroidectomy. In a separate study, serum intact PTH concentrations were measured by immunoradiometric assay (kit from Nichols Institute, San Juan Capistrano, CA) in another series of Graves' patients before and after surgery. In patients whose serum $\mathrm{Ca}$ decreased markedly, serum intact PTH decreased, and the pattern of change was similar for serum M-PTH (data not shown).

However, transient hypoparathyroidism cannot be the only cause of transient hypocalcemia. In the overt postoperative hypoparathyroidism observed in the case of Y.S., serum $\mathrm{P}$ and \% TRP increased in association with a decrease in serum Ca. Unlike this, serum $P$ and \%TRP decreased in cases of transient hypocalcemia. Urinary $P$ excretion in addition to urinary $\mathrm{Ca}$ excretion increased after surgery. Decreased tubular reabsorption of $\mathrm{Ca}$ might be due to decrease $\mathrm{PTH}$, but the increase in urinary $P$ excretion cannot be explained by hypoparathyroidism. The release of CT has been reported to be a mechanism for early post-thyroidectomy hypocalcemia (Wilkin et al., 1977; Watson et al., 1981). We have also studied the role of $\mathrm{CT}$ in transient hypocalcemia (Mimura et al., 1982) and found that serum CT increased after surgery but its increase was very small and there was no significant correlation between the degree of increase in CT and the degree of decrease in Ca. However, a slight increase in serum CT might decrease renal tubular reabsorption of both $\mathrm{P}$ and Ca (Ardaillou et al., 1967), resulting in increases in urinary $\mathrm{Ca}$ and $\mathrm{P}$ excretion. Moreover, an acute decrease in serum $\mathrm{T}_{3}$ and $\mathrm{T}_{4}$ after subtotal thyroidectomy (Mimura et al., 1982) may result in decreased reabsorption of $\mathrm{P}$, since thyroxine administration increase proximal reabsorption of $\mathrm{P}$ in thyroparathyroidectomized rats
(Espinosa et al., 1984).

Another possible mechanism for transient hypocalcemia after subtotal thyroidectomy for Graves' disease is the reversal of thyrotoxic osteodystrophy (Michie et al., 1971; Latien, 1976). However, if the return of $\mathrm{Ca}$ to bone were the mechanism leading to postoperative hypocalcemia, it would be expected that PTH increased and that serum CT decreased, but in fact those changed in opposite ways (Wilkin et al., 1977; Watson et al., 1981). Various factors including the effects of the acute decrease in serum $\mathrm{T}_{3}$ and $\mathrm{T}_{4}$ on the action of PTH and vitamin $\mathrm{D}$ (Castro et al., 1975; Pavlovich et al., 1977) may modulate the $\mathrm{Ca}$ and $\mathrm{P}$ metabolism after subtotal thyroidectomy for Graves' disease. However, transient insufficiency of the parathyroid gland may be a main cause of post-thyroidectomy hypocalcemia.

\section{References}

Ardaillou, R., P. Vuagnat, G. Milhaud and G. Richet (1967). Effets de la thyrocalcitonine sur 1'excretion renale des phosphates du calcium et des ions $\mathrm{H}^{+}$ches 1 'homme. Nephron 4, 298-314.

Berson, S. A., R. S. Yalow, G. D. Aurbach and J. T. Potts, Jr. (1963). Immunoassay of bovine and human parathyroid hormone. Proc. Natl. Acad. Sci. USA 4, 613-617.

Broadus, A. E., J. E. Mahaffey, F. C. Bartter and R. M. Neer (1977). Nephrogenous cyclic adenosine monophosphate as a parathyroid function test. J. Clin. Invest. 60, 771-783.

Castro, J. H., S. M. Genth and L. Klein (1975). Comparative response to parathyroid hormone in hyperthyroidism and hypothyroidism. Metabolism 24, 839-848.

Davis, R. H., P. Fourman and J. W. G. Smith (1961). Prevalence of parathyroid insufficiency after thyroidectomy. Lancet 2, 1432-1435.

Espinosa, R. E., M. J. Keller, A. N. K. Yusufi and T. P. P. Duosa (1984). Effects of thyroxine administration on phosphate transport across renal cortical brush border membrane. Am. J. Physiol. 246, F 133-139. 
European, P. T. H. Study Group (1978). Interlaboratory comparison of radioimmunological parathyroid hormone determination. Eur. $J$. Clin. Invest. 8, 149-154.

Fukunaga, M. S. Doko, I. Yamamoto, R. Morita K. Torizuka and K. Kuma (1977). Clinical investigation of calcitonin radioimmunoassay. Bone Metabolism 10, 121-125 (Japanese).

Fukunaga, M., N. Otsuka, T. Furukawa and R. Morita (1987). Fundamental and clinical study for PTH (parathyroid hormone) kit "Yamasa". Kakuigaku 24, 319-325 (Japanese)

Hurska, K. A., R. Kopelman, W. E. Rutherford, S. Klahr and E. Slatopolsky (1975). Metabolism of immunoreactive parathyroid hormone in the dog. J. Clin. Invest. 56, 39-48.

Ishihara, S., S. Tsujioka, J. Motogi, S. Honda, M. Tomonobe, K. Kanao, N. Fushimi, B. Kishino, M. Nishikawa, H. Itatani and $H$. Morii (1984). Evaluation of radioimmunoassay system using c-terminal parathyroid hormone fragment (46-84). Clinical Endocrinology 32, 1009-1013 (Japanese).

Kawakubo, A., M. Kurokawa, M. Yoneda, S. Kawakita, K. Takatsuki and A. Tomita (1986), Basic and clinical studies on serum parathyroid hormone using the radioimmunoassay kit "Yamasa" Clinical. Endocrinology 34, 1065-1069 (Japanese).

Kobayashi, S. (1981). Studies on etiology of postoperative transient tetany following thyroidectomy for hyperthyroidism. J. Jap. Sug. Soc. 82, 130-138 (Japanese).

Latinen, O. (1976). Hypocalcemia following thyroidectomy. Lancet 2, 859-860.

Michie, W., T. Duncan, D. W. Hamer-Hodges, J. M. Stowers, C. A. S. Pegg, G. Hems, P. D.
Bewsher and A. J. Hedley (1971). Mechanism of hypocalcemia after thyroidectomy for thyrotoxicosis. Lancet 1, 508-513.

Mimura, T., N. Hamada, Y. Ban, H. Mori, H. Momotani, H. Takami, Y. Nishikawa and K. Ito (1982). Anterior pituitary, thyroid, parathyroid, and adrenal responses to subtotal thyroidectomy in patients with Graves' disease. Jpn. J. Surg. 12, 235-241.

Pavlovich, H, V. Presle and S. Balsan (1977). Decreased bone sensitivity of thyroidectomized rats to the calcaemic effect of 1,25-dihydrooxycholecalciferol. Acta Endocrinol. 84, 774779.

Percival, R. C., A. W. Hargreaves and J. A. Kanis (1981). The mechanism of hypocalcemia following thyroidectomy. Acta Endocrinol. 109, 220-226.

Ridell, V. (1962). Thyrotoxicosis and the surgeon. Br. J. Surg. 49, 465-496.

Voll, R., H. Schmidt-Gayk, J. Wiedmann, M. Hufner, R. Bouillon, H. Keutmann and R. Hehrmann (1978). Radioimmunoassay for parathrin: characterization of six different antigens and antisera. J. Clin. Chem. Clin. Biochem. 16, 269-277.

Watson, C. G., D. L. Steed, A. G. Robinson and Deftos (1981). The role of calcitonin and parathyroid hormone in the pathogenesis of post-thyroidectomy hypocalcemia. Metabolism 30, 588-589.

Wilkin, T. J., C. R. Paterson, T. E. Isles, J. Crooks and J. Swanson-Beck (1977). Postthyroidectomy hypocalcemia. A feature of the operation of the thyroid disorder. Lancet 1, 621-623. 